\title{
Experimental Study on Impact Damage of Concrete Bridge Pier with Closed-cell Foam Aluminum Buffer Materials
}

\author{
Xiwu Zhou ${ }^{1}$, Kai Zhao ${ }^{2}$, BenYing Wu ${ }^{3}$ and WenChao Zhang ${ }^{4}$ \\ 1 Associate professor,School of Transportation and Civil Engineering \& Architecture, Foshan \\ University, Foshan, P.R. China \\ 2 Master Degree Candidate,School of Transportation and Civil Engineering \& Architecture, Foshan \\ University, Foshan, P.R. China \\ 3 Senior experimentalist,School of Transportation and Civil Engineering \& Architecture, Foshan \\ University, Foshan, P.R. China \\ 4 Master Degree Candidate,School of Transportation and Civil Engineering \& Architecture, Foshan
University, Foshan, P.R. China

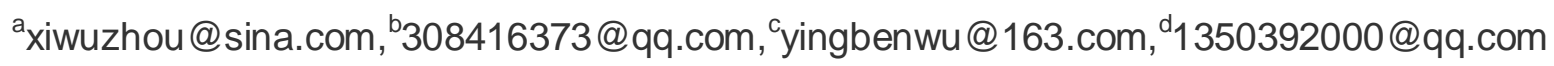

Keywords: Reinforced concrete; Bridge pier; Horizontal collision; Foam aluminum buffer material; Damage performance

\begin{abstract}
The domestically most advanced ultrahigh drop-hammer impact test system was used to simulate the ship-bridge collision under the impact load effect of horizontal collision. In accordance with the similarity principle, 4 reinforced concrete bridge pier specimens were fabricated according to the proportion of 1:5, and closed-cell foam aluminum buffer material with different thicknesses and densities was designed at the impact cart head to study the influence of closed-cell foam aluminum buffer material on the damage performance of reinforced concrete bridge pier specimen. The result showed that, after multiple impacts on the reinforced concrete bridge pier specimens with the same energy, the specimens using closed-cell foam aluminum as the buffer material had a smaller crack width and damage factor than the specimens without using it; under the low-energy impact effect, the buffer effect of closed-cell foam aluminum was not obvious; under the high-energy impact effect, the buffer effect of closed-cell foam aluminum was relatively obvious, and the scheme of doubling the density of closed-cell foam aluminum had a better buffer effect than the scheme of doubling the thickness.
\end{abstract}

In recent years, ship-bridge pier collision accidents have occurred frequently with the increase of shipping traffic volume. This kind of accident will cause huge economic loss and casualties ${ }^{[1]}$. Impact load is a kind of very complicated dynamic load, which not only causes structural damage and failure, but also is more likely to cause damage to the structure. Closed-cell aluminum foam, as an excellent impact buffer material, can effectively reduce structural damage. Therefore, it is very important to study the effect of aluminum foam with different thicknesses and densities on the damage performance of structural concrete.

Many scholars have studied the damage performance of concrete structure under the impact load effect. Wang Shiming ${ }^{[2]}$ systematically studied the mechanical property, breaking condition and damage performance of early-age concrete under different impact load effects. Tian Yubin et al ${ }^{[3]}$ adopted drop-hammer impact tester to firstly perform impact test on the concrete prism specimen and then implement the axial compression test, resulting in the stress-strain relation curve of concrete specimens with different damage degrees. Tian $\mathrm{Li}$ et $\mathrm{al}^{[4]}$, regarding the collision of rigid ball with reinforced concrete column as the research basis, studied the damage evaluation and protection technique of reinforced concrete column under the impact load effect. Huang Tao et al ${ }^{[5]}$ studied the concrete damage status of concrete prism after the drop-hammer impact test, ultrasonic detection test and pressure test. H.Ohnuma et $\mathrm{al}^{[6]}$ studied the failure mode of reinforced concrete members through the structural test. Cook $^{[7]}$ et al studied the influence of tensile load history on the deterioration of concrete strength and rigidity. Many scholars also have made related studies on the foam aluminum as the impact buffer material. Lan Fengchong et al ${ }^{[8]}$ analyzed the energy 
absorption ability and impact resistance ability of closed-cell foam aluminum, summarized the progress of research on the influence (or not) of strain rate and impact velocity on the energy absorption ability of foam aluminum and explained the possible influence. Kang Yingan et al ${ }^{[9]}$ studied the influence of relative density on the mechanical property and energy absorption capacity of foam aluminum. Zhang Fuzeng used ${ }^{[10]}$ the LS-DYNA finite element software to simulate the impact prevention effect of the flexible energy absorption structure of sandwich foam aluminum. Zhu Cong ${ }^{[11]}$ studied the reinforcement and protection of reinforced concrete column under the collision impact load effect, and compared the impact prevention effect of two reinforcement measures (external sticking steel plate and external applied foam aluminum) in view of the composite cross-sectional reinforcement. Xu Dongfeng ${ }^{[12]}$ conducted pendulum impact test on the bridge pier equipped with closed-cell foam aluminum protection device and then implemented comparative analysis on the law of influence of foam aluminum on bridge pier by using the stress and acceleration as the evaluation index. Liu Huan ${ }^{[13]}$, in view of the energy-absorption capability of foam aluminum material, studied the mechanical behaviors of closed-cell foam aluminum and filled foam aluminum pipe under the conditions of quasi-static compression and low-speed impact. Li Binchao et $\mathrm{al}^{[14]}$ established the analysis model for the low-speed impact of high-porosity closed-cell foam aluminum and verified the model prediction accuracy through the drop-hammer impact test. Santosa and Wierzbicki ${ }^{[15]}$ studied the crushing behavior of closed-cell foam aluminum by using the theoretical and numerical analysis method. Yu et $\mathrm{al}^{[16]}$, through the experimental graph of foam aluminum under the static and dynamic state, reached an conclusion that the foam aluminum with a higher relative density had an obviously higher yield point elongation and flow stress that the foam aluminum with a low relative density.

At present, there are many research results on the damage performance of reinforced concrete structure under the impact load effect and research results on the foam aluminum used as the impact prevention buffer material, but there is little research on the damage performance of reinforced concrete structure after combination of them (i.e., using foam aluminum as the impact prevention buffer materials), so further study in this aspect is required. Through comparing the changes of sound velocity, damage factor and crack developing in the main damage area of reinforced concrete bridge pier specimens before after each impact test, this paper analyzed the influence of the closed-cell foam aluminum buffer material with different thicknesses and densities on the damage performance of reinforced concrete.

\section{Experiment Scheme}

\section{Design of Specimen}

In accordance with the similarity principle, 4 reinforced concrete bridge pier specimens were designed by regarding the double-column pier of a bridge as the experiment prototype and by using the reduced scale of 1:5 to make the bridge pier model. The specimens have a height of $2200 \mathrm{~mm}$ and diameter of $340 \mathrm{~mm}$, and four holes are reserved on the specimen base to install high-strength bolt for purpose of fixing of bridge pier specimen. The specimens use C40 concrete, HRB335 longitudinal bar and HPB300 stirrup with diameter of $8 \mathrm{~mm}$; the experiment column uses the symmetric reinforcement, and welding construction method is used for the reinforcement; and Fig. 1 shows the reinforcement drawing for the specimens. This experiment totally designs three pieces of closed-cell foam aluminum buffer materials, with a length of $210 \mathrm{~mm}$ and width of $100 \mathrm{~mm}$. The parameters of foam aluminum materials are as shown in the table 1, the design parameters of specimens are as shown in the table 2, the performance of reinforcement materials is as shown in the table 3 and the mechanical property of concrete is as shown in the table 4 . 


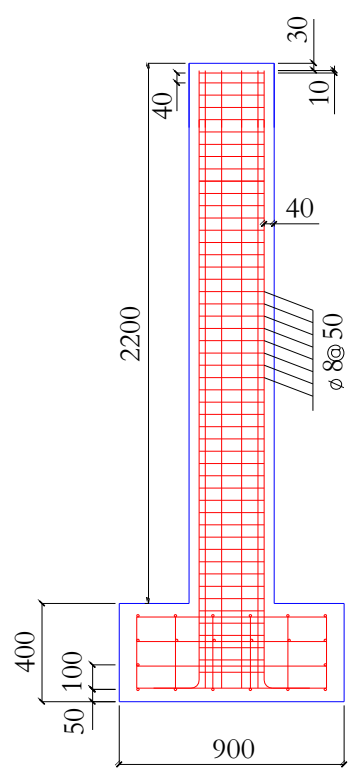

(a)
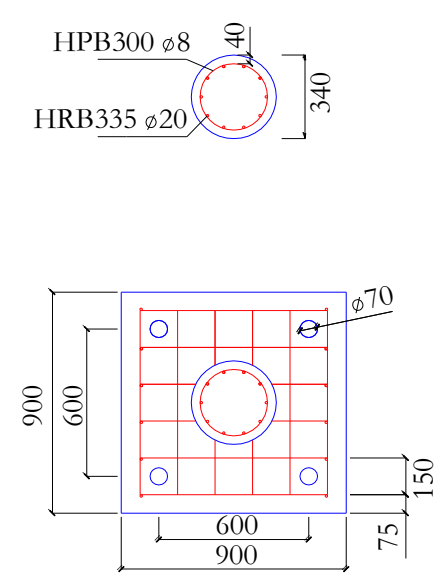

(b)

Figure 1. Schematic Diagram for Specimen (Dimension Unit: mm)

Table 1 Table for the Thickness and Density Parameters of Foam Aluminum

\begin{tabular}{llllll}
\hline $\begin{array}{l}\text { Materia } \\
\text { 1 No. }\end{array}$ & $\begin{array}{l}\text { Thickness } \\
(\mathrm{mm})\end{array}$ & $\begin{array}{l}\text { Density } \\
\left(\mathrm{g} / \mathrm{cm}^{3}\right)\end{array}$ & $\begin{array}{l}\text { Mean } \\
\text { Size }(\mathrm{mm})\end{array}$ & $\begin{array}{l}\text { Pore } \\
\text { Strength } \\
(\mathrm{MPa})\end{array}$ & $\begin{array}{l}\text { Tensile } \\
\text { Strength } \\
(\mathrm{MPa})\end{array}$ \\
\hline A1 & 50 & 0.40 & 1.4 & 7.0 & 3.6 \\
A2 & 100 & 0.40 & 1.4 & 7.0 & 3.6 \\
A3 & 50 & 0.72 & 1.7 & 22.3 & 7.9 \\
\hline
\end{tabular}

Table 2 Design Parameters of Specimens

\begin{tabular}{|c|c|c|c|c|}
\hline $\begin{array}{l}\text { Specime } \\
\text { n No. }\end{array}$ & $\begin{array}{l}\text { Longitudinal } \\
\text { Reinforcement }\end{array}$ & Stirrup & $\begin{array}{l}\text { Strength Grade of } \\
\text { Concrete }\end{array}$ & $\begin{array}{l}\text { Foam Aluminum No. } \\
\text { Used for Specimen }\end{array}$ \\
\hline Z20-1 & $10 \Phi 20$ & Ф8@50 & $\mathrm{C} 40$ & None \\
\hline Z20-2 & $10 \Phi 20$ & Ф8@50 & C40 & A1 \\
\hline $\mathrm{Z} 20-3$ & $10 \Phi 20$ & Ф8@50 & $\mathrm{C} 40$ & $\mathrm{~A} 2$ \\
\hline Z20-4 & 10Ф20 & Ф8@50 & C40 & A3 \\
\hline
\end{tabular}

Table 3 Material Performance of Reinforcement

\begin{tabular}{lllll}
\hline Type of Reinforcement & $\begin{array}{l}\text { Yield } \\
\text { Strength/MPa }\end{array}$ & $\begin{array}{l}\text { Tensile } \\
\text { Strength/MPa }\end{array}$ & $\begin{array}{l}\text { Elasticity } \\
\text { E(MPa) }\end{array}$ & Modulus \\
\hline $\begin{array}{l}\text { Longitudinal } \\
\text { reinforcement HRB335 }\end{array}$ & 358 & 458 & $2.00 \times 10^{5}$ & \\
Stirrup HPB300 & 320 & 435 & $2.10 \times 10^{5}$ & \\
\hline
\end{tabular}

Table 4 Mechanical Property of Concrete

\begin{tabular}{lll}
\hline & $\begin{array}{l}\text { Standard } \\
\text { Compressive Strength }(\mathrm{MPa})\end{array}$ & Elasticity Modulus E (MPa) \\
\hline C40 concrete & 57.8 & $3.25 \times 10^{4}$ \\
\hline
\end{tabular}




\section{Experiment Devices}

This test uses the domestically most advanced multi-functional ultrahigh heavy type drop-hammer tester system with the cart weight of $1.2 \mathrm{t}$; the axial pressure of specimen is designed to be $250 \mathrm{kN}$ and the axial pressure is applied by jack, as shown in the Fig.2; the axial pressure can be maintained at a stable state during the test. The mass of drop hammer for testing is designed to be $196 \mathrm{~kg}$, and the falling of drop hammer (as shown in the Fig.3) can drive the cart to impact the specimen; the cart can impact the specimen at a designed speed by changing the lifting height of drop hammer. In the bottom and middle area of specimen, 20 measurement points are evenly taken along the height direction of specimens, and grids with side length of $5 \mathrm{~cm}$ are drawn at the location of each measurement point to improve the measurement accuracy, as shown in the Fig.4. The closed-cell foam aluminum buffer material is fixed at the head location of the impact cart, as shown in the Fig.5.

The drop hammer is lifted to a certain height during the impact test, and this process guarantees that the steel wire rope connecting the drop hammer is in a tensile state; after that, the drop hammer is suddenly released to drive the cart to impact the specimen, and its systematic diagram is as shown in the Fig.6. ZBL-U520 non-mental ultrasonic concrete detection instrument is used to detect the main failure area of specimen.

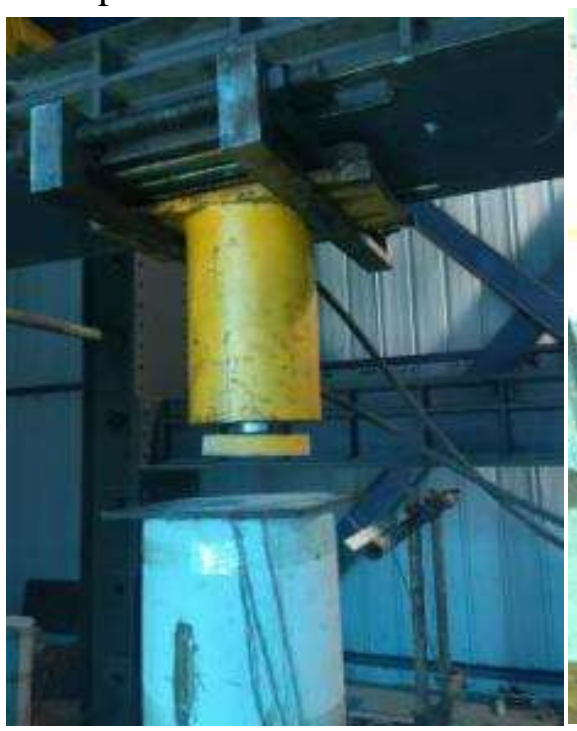

Figure 2. Impacted Specimen Figure

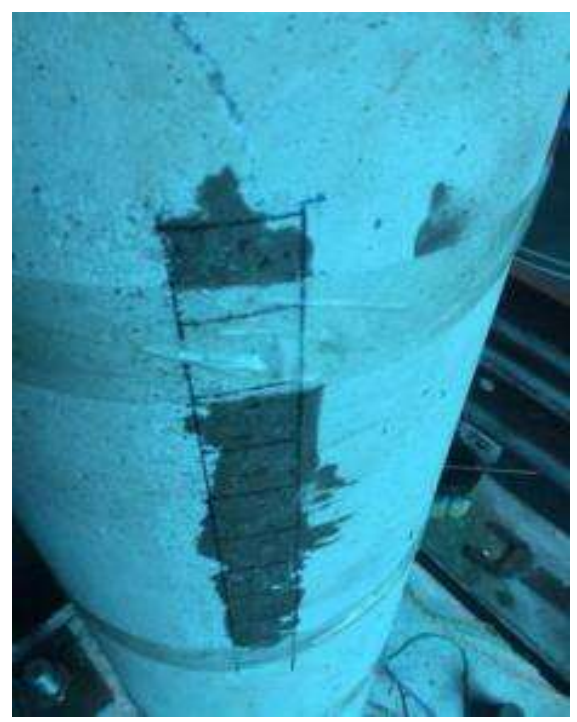

Figure 4. Detection Area of Specimen

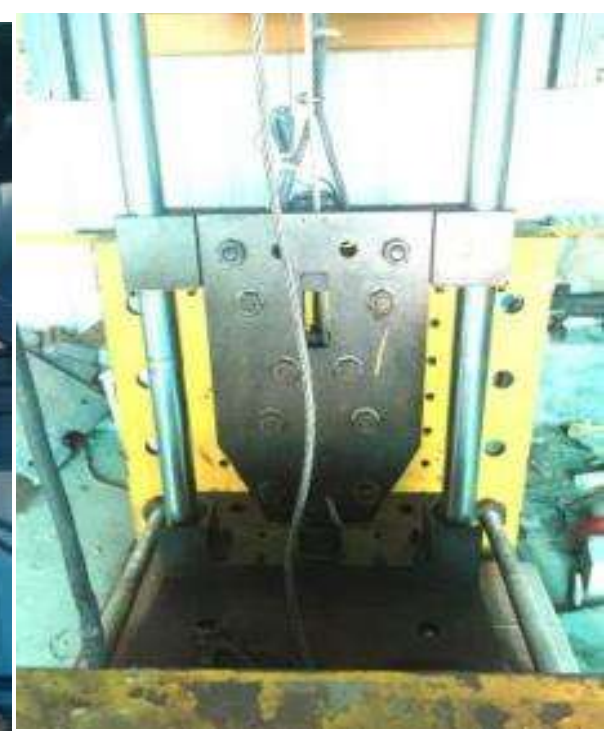

Figure 3. Drop-hammer Tester Figure

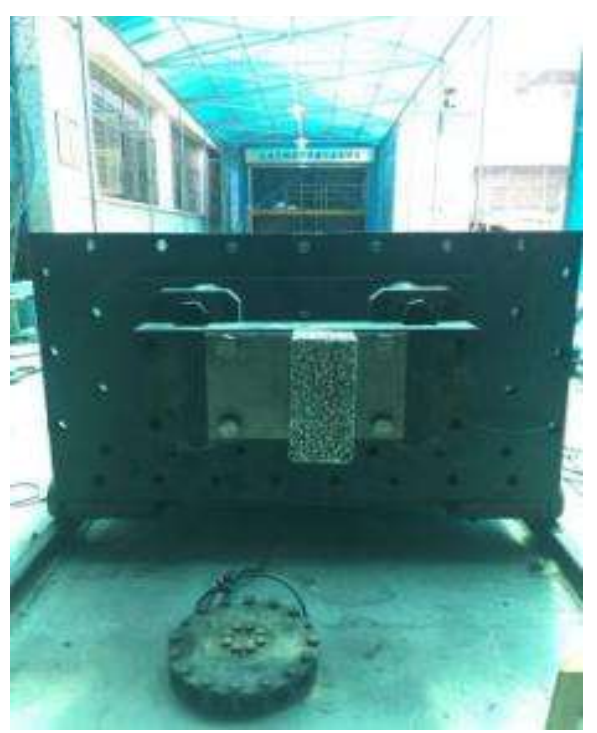

Figure 5. Impact Cart 


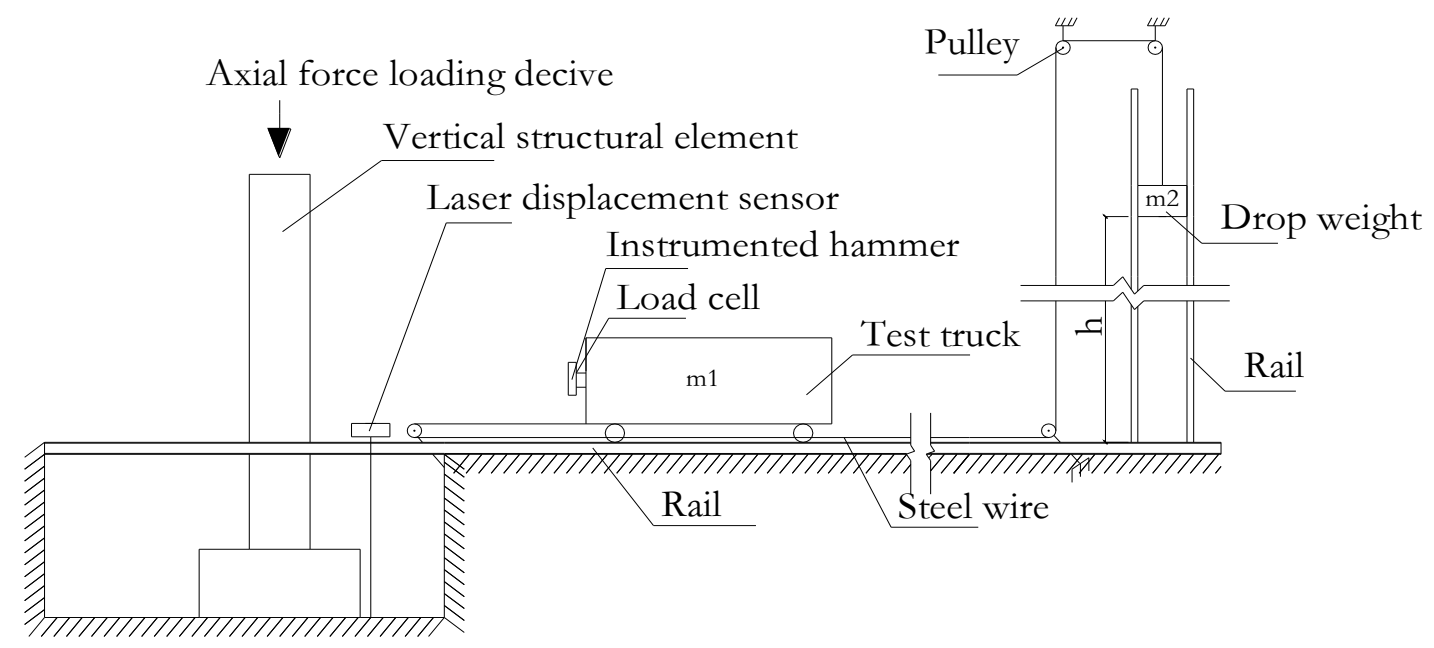

Figure 6. Schematic Diagram for Impact

\section{Experimental Analysis}

\section{Crack Analysis}

The initial crack of each specimen is formed in the bottom area of the impact surface. With the increase of impact velocity, the crack develops from the bottom of crack surface to the middle direction, and cracks start to appear in the back surface area of the impact point; with the continuous increase of impact velocity, the original crack at the lower middle part of the front surface continues to develop and also continues to develop towards the middle area; meanwhile, the cracks on the back surface of impact continue to develop towards the upper middle area. When the impact velocity reaches a certain value, larger cracks will occur in the bottom area of the front impact surface (about $150 \mathrm{~mm}$ to the bottom), and these cracks are regarded as the major cracks; part of concrete at the bottom of the impact back surface will be crushed, and the middle area of impact back surface will occur long and thin cracks; the development area of crack is very consistent with the main stressing area of specimen, and the failure mode of the final impact specimen is as shown in the Fig.7. 


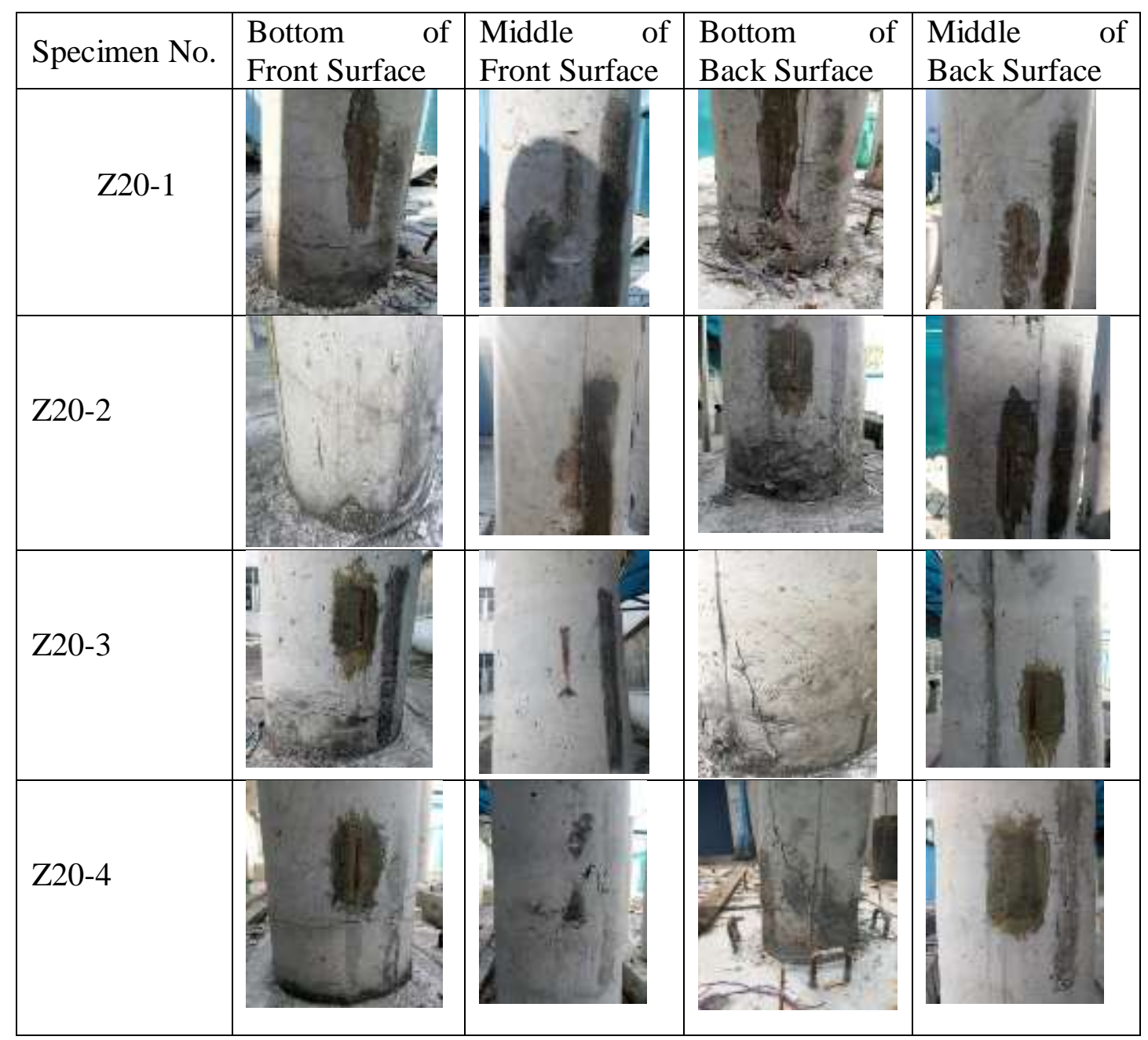

Figure 7. Specimen Cracks

It can be known from the analysis that the width of major cracks shows a certain law, which can be used as the basis for evaluating the damage degree of specimen. The width of major cracks of each specimen under each impact is as shown in the table 5.

Table 5 Crack Development under Different Impact Energies

\begin{tabular}{lllllll}
\hline \multirow{2}{*}{ Specimen } & \multicolumn{6}{l}{$\begin{array}{l}\text { Width (mm) of Major Cracks under each Height } \\
\text { of Drop Hammer }\end{array}$} \\
\cline { 2 - 7 } & $2 \mathrm{~m}$ & $4 \mathrm{~m}$ & $6 \mathrm{~m}$ & $8 \mathrm{~m}$ & $10 \mathrm{~m}$ & $12 \mathrm{~m}$ \\
\hline $\mathrm{Z} 20-1$ & 0 & 0 & 0.070 & 0.160 & 0.270 & 0.620 \\
$\mathrm{Z} 20-2$ & 0 & 0 & 0 & 0.050 & 0.120 & 0.260 \\
$\mathrm{Z} 20-3$ & 0 & 0 & 0 & 0 & 0.120 & 0.240 \\
Z20-4 & 0 & 0 & 0 & 0 & 0.080 & 0.160 \\
\hline
\end{tabular}

After comparing Z20-1 with Z20-2 in the table 5, it can be known that the closed-cell foam aluminum buffer materials can absorb a certain impact energy during the impact, which can delay the derivation and development of impact cracks. After comparing Z20-2 with Z20-3 and Z20-4 respectively, it can be known that approximate doubling of closed-cell foam aluminum density has more significant buffer effect than doubling of thickness.

\section{Ultrasonic Velocity Analysis}

In order to analyze the specimen damage status before and after impact, HC-U8 multi-functional concrete ultrasonic tester is used in the experiment to detect the main impact damage position of specimen and sound velocity is used as the index in the experiment to analyze the impact damage status of specimen. The ultrasonic velocity detection value of each impact specimen is as shown in 
the table 6.

Table 6 Change of Ultrasonic Velocity of Each Specimen after Impact

\begin{tabular}{|c|c|c|c|c|c|c|}
\hline \multirow{2}{*}{$\begin{array}{l}\text { Specim } \\
\text { en }\end{array}$} & \multirow{2}{*}{$\begin{array}{l}\text { Lifting } \\
\text { height of } \\
\text { Drop } \\
\text { Hammer } \\
(\mathrm{m})\end{array}$} & $\begin{array}{l}\text { Average } \\
\text { Velocity }\end{array}$ & $\begin{array}{c}\text { Sound } \\
(\mathrm{km} / \mathrm{s})\end{array}$ & \multirow{2}{*}{$\begin{array}{l}\text { Reduction } \\
\text { of sound } \\
\text { velocity } \\
(\mathrm{km} / \mathrm{s})\end{array}$} & \multirow{2}{*}{$\begin{array}{l}\text { Total } \\
\text { reduction of } \\
\text { sound velocity } \\
(\mathrm{km} / \mathrm{s})\end{array}$} & \multirow{2}{*}{$\begin{array}{l}\text { Average } \\
\text { change } \\
\text { rate of } \\
\text { sound } \\
\text { velocity }\end{array}$} \\
\hline & & $\begin{array}{l}\text { Before } \\
\text { Impact }\end{array}$ & $\begin{array}{l}\text { After } \\
\text { impact }\end{array}$ & & & \\
\hline \multirow{6}{*}{ Z20-1 } & 2 & 4.319 & 4.252 & -0.067 & \multirow{6}{*}{-1.250} & \multirow{6}{*}{$28.9 \%$} \\
\hline & 4 & 4.252 & 4.141 & -0.111 & & \\
\hline & 6 & 4.141 & 3.982 & -0.159 & & \\
\hline & 8 & 3.982 & 3.754 & -0.228 & & \\
\hline & 10 & 3.754 & 3.451 & -0.303 & & \\
\hline & 12 & 3.451 & 3.069 & -0.382 & & \\
\hline \multirow{6}{*}{ Z20-2 } & 2 & 4.328 & 4.271 & -0.057 & \multirow{6}{*}{-0.952} & \multirow{6}{*}{$22 \%$} \\
\hline & 4 & 4.271 & 4.177 & -0.094 & & \\
\hline & 6 & 4.177 & 4.038 & -0.139 & & \\
\hline & 8 & 4.038 & 3.847 & -0.191 & & \\
\hline & 10 & 3.847 & 3.635 & -0.212 & & \\
\hline & 12 & 3.635 & 3.376 & -0.259 & & \\
\hline \multirow{6}{*}{ Z20-3 } & 2 & 4.343 & 4.297 & -0.046 & \multirow{6}{*}{-0.818} & \multirow{6}{*}{$18 \%$} \\
\hline & 4 & 4.297 & 4.233 & -0.064 & & \\
\hline & 6 & 4.193 & 4.085 & -0.108 & & \\
\hline & 8 & 4.085 & 3.928 & -0.157 & & \\
\hline & 10 & 3.928 & 3.751 & -0.177 & & \\
\hline & 12 & 3.751 & 3.525 & -0.226 & & \\
\hline \multirow{6}{*}{ Z20-4 } & 2 & 4.335 & 4.305 & -0.030 & \multirow{6}{*}{-0.630} & \multirow{6}{*}{$14.5 \%$} \\
\hline & 4 & 4.305 & 4.249 & -0.056 & & \\
\hline & 6 & 4.249 & 4.161 & -0.088 & & \\
\hline & 8 & 4.161 & 4.038 & -0.123 & & \\
\hline & 10 & 4.038 & 3.887 & -0.151 & & \\
\hline & 12 & 3.887 & 3.705 & -0.182 & & \\
\hline
\end{tabular}

Table 6 shows the change of acoustic parameters after concrete damage of specimen impact when the drop hammer is lifted to the height of $2 \mathrm{~m}, 4 \mathrm{~m}, 6 \mathrm{~m}, 8 \mathrm{~m}, 10 \mathrm{~m}$ and $12 \mathrm{~m}$ respectively. It can be known from the table 6 that the changes of ultrasonic waves of specimen impact have the generally consistent trend of reduction; after multiple impacts of specimen, it can be known by comparing Z20-1 with Z20-2 that the sound velocity change rate of specimen using the closed-cell foam aluminum is reduced by $6.9 \%$, which means that the closed-cell foam aluminum buffer materials can significantly weaken the concrete impact damage of specimen; it can be known by comparing Z20-2 with Z20-3 and Z20-4 that the average sound velocity change rate 18\% after doubling the thickness of foam aluminum is obviously higher than the average sound velocity change rate $14.5 \%$ after approximate doubling of foam aluminum density, which means that the density doubling scheme is superior to the thickness doubling scheme in the impact prevention design by using the closed-cell foam aluminum materials. 


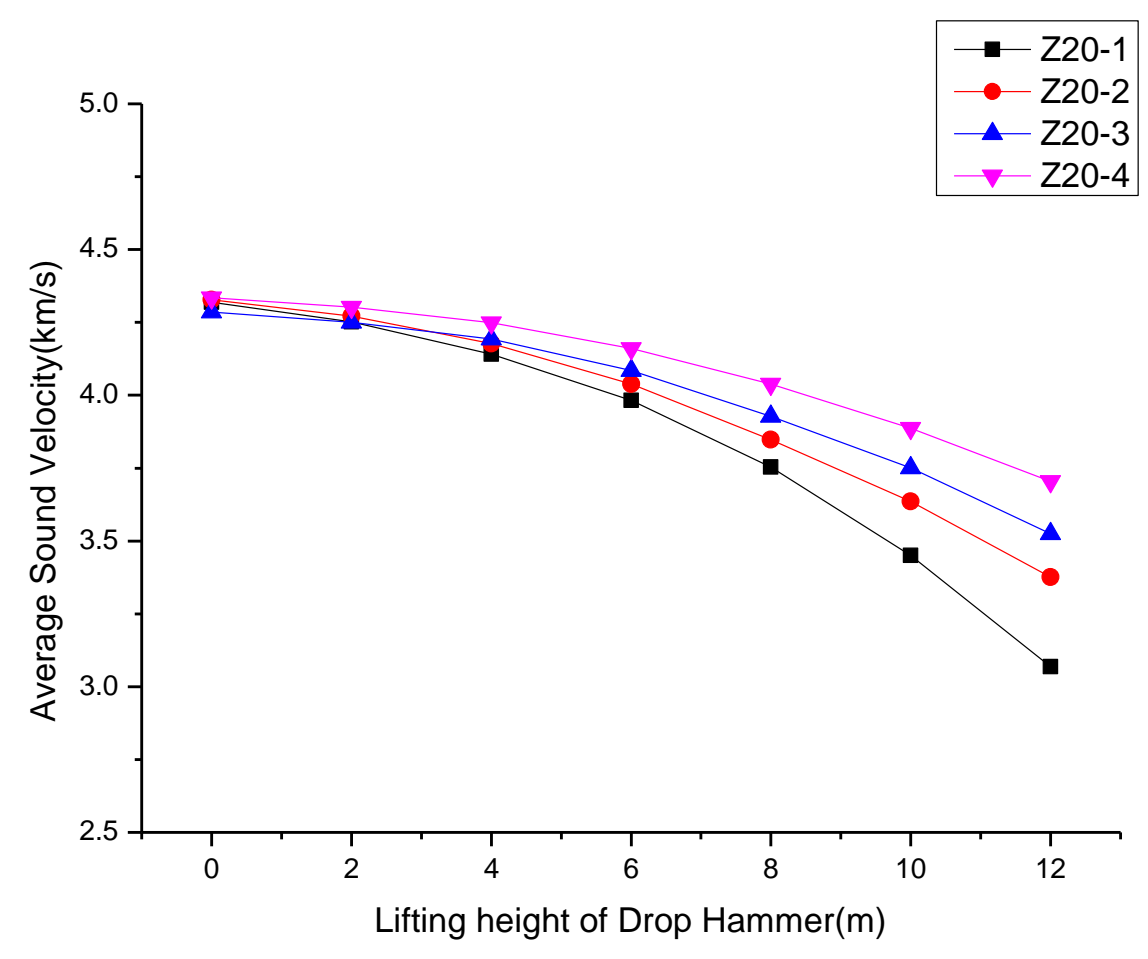

Figure 8. Diagram for the Average Sound Velocity Change of Ultrasonic Wave

Fig. 8 shows the average sound velocity changes of ultrasonic wave at the main damage position of specimen when the drop hammer is lifted to the height of $2 \mathrm{~m}, 4 \mathrm{~m}, 6 \mathrm{~m}, 8 \mathrm{~m}, 10 \mathrm{~m}$ and $12 \mathrm{~m}$ respectively. It can be known from the Fig. 8 that the average sound velocity changes of ultrasonic wave of specimen have a smaller difference when the drop hammer is lifted to the height of $0-4 \mathrm{~m}$ during the low-energy impact, which means that the specimen damage is small during the low-energy impact and the closed-cell foam aluminum has not obvious buffer effect; if the drop hammer is lifted to the height of $8-12 \mathrm{~m}$ during the high-energy impact, the average sound velocity changes of ultrasonic waves of concrete have a large difference, which means that the specimen damage is large during the high-energy impact, the buffer effect of closed-cell foam aluminum is obvious and the approximate density doubling of the closed-cell foam aluminum has a better buffer effect than the thickness doubling scheme.

\section{Analysis of Damage Factors}

The damage factor $\mathrm{D}$ is introduced to make quantitative analysis on the damage degree, $\mathrm{D}=1-\mathrm{v}^{2} / \mathrm{v}_{0}{ }^{2}$ (where, $\mathrm{v}$ represents the sound velocity of ultrasonic wave after impact, and $\mathrm{v} 0$ represents the sound velocity of ultrasonic wave before the impact). 
Table 7 Parameter Changes of Concrete Damage Factors

\begin{tabular}{|c|c|c|c|c|c|}
\hline \multirow{2}{*}{$\begin{array}{l}\text { Speci } \\
\text { men }\end{array}$} & \multirow{2}{*}{$\begin{array}{l}\text { Impact } \\
\text { Height }\end{array}$} & \multicolumn{2}{|l|}{ Damage Factor } & \multirow{2}{*}{$\begin{array}{l}\text { Increase of } \\
\text { damage } \\
\text { factor }\end{array}$} & \multirow{2}{*}{$\begin{array}{l}\text { Total } \\
\text { increase } \\
\text { damage } \\
\text { factor }\end{array}$} \\
\hline & & Before impact & After impact & & \\
\hline \multirow{6}{*}{$\begin{array}{l}\text { Z20- } \\
1\end{array}$} & $2 \mathrm{~m}$ & 0 & 0.03 & 0.03 & \multirow{6}{*}{0.21} \\
\hline & $4 \mathrm{~m}$ & 0.03 & 0.05 & 0.02 & \\
\hline & $6 \mathrm{~m}$ & 0.05 & 0.08 & 0.03 & \\
\hline & $8 \mathrm{~m}$ & 0.08 & 0.11 & 0.03 & \\
\hline & $10 \mathrm{~m}$ & 0.11 & 0.15 & 0.04 & \\
\hline & $12 \mathrm{~m}$ & 0.15 & 0.21 & 0.06 & \\
\hline \multirow{6}{*}{$\begin{array}{l}\text { Z20- } \\
2\end{array}$} & $2 \mathrm{~m}$ & 0 & 0.03 & 0.03 & \multirow{6}{*}{0.14} \\
\hline & $4 \mathrm{~m}$ & 0.03 & 0.04 & 0.01 & \\
\hline & $6 \mathrm{~m}$ & 0.04 & 0.07 & 0.03 & \\
\hline & $8 \mathrm{~m}$ & 0.07 & 0.09 & 0.02 & \\
\hline & $10 \mathrm{~m}$ & 0.09 & 0.11 & 0.02 & \\
\hline & $12 \mathrm{~m}$ & 0.11 & 0.14 & 0.03 & \\
\hline \multirow{6}{*}{$\begin{array}{l}\text { Z20- } \\
3\end{array}$} & $2 \mathrm{~m}$ & 0 & 0.02 & 0.02 & \multirow{6}{*}{0.12} \\
\hline & $4 \mathrm{~m}$ & 0.02 & 0.03 & 0.01 & \\
\hline & $6 \mathrm{~m}$ & 0.03 & 0.05 & 0.02 & \\
\hline & $8 \mathrm{~m}$ & 0.05 & 0.08 & 0.03 & \\
\hline & $10 \mathrm{~m}$ & 0.08 & 0.09 & 0.01 & \\
\hline & $12 \mathrm{~m}$ & 0.09 & 0.12 & 0.03 & \\
\hline \multirow{6}{*}{$\begin{array}{l}\text { Z20- } \\
4\end{array}$} & $2 \mathrm{~m}$ & 0 & 0.01 & 0.01 & \multirow{6}{*}{0.09} \\
\hline & $4 \mathrm{~m}$ & 0.01 & 0.02 & 0.01 & \\
\hline & $6 \mathrm{~m}$ & 0.02 & 0.04 & 0.02 & \\
\hline & $8 \mathrm{~m}$ & 0.04 & 0.06 & 0.02 & \\
\hline & $10 \mathrm{~m}$ & 0.06 & 0.07 & 0.01 & \\
\hline & $12 \mathrm{~m}$ & 0.07 & 0.09 & 0.02 & \\
\hline
\end{tabular}

Table 7 shows the changes of concrete damage factors of specimen when the drop hammer is lifted to the height of $2 \mathrm{~m}, 4 \mathrm{~m}, 6 \mathrm{~m}, 8 \mathrm{~m}, 10 \mathrm{~m}$ and $12 \mathrm{~m}$ respectively. It can be known by comparing the specimen Z20-1 with Z20-2 that the specimen using the closed-cell foam aluminum has an obviously smaller damage factor than that without using the closed-cell foam aluminum and the damage factor of specimen Z20-2 is lower than the specimen Z20-1 by 0.07, which means that the use of closed-cell foam aluminum as the buffer material of specimen can effectively reduce the impact damage of concrete specimen. After comparing the specimen Z20-2 with Z20-3 and Z20-4, it can be found that the damage factor of specimen can be reduced by 0.02 when the foal aluminum thickness is doubled, and the damage factor of specimen can be reduced by 0.05 when the foam aluminum density is approximately doubled, which means that the density doubling scheme of the closed-cell foam aluminum has a better buffer effect that the thickness doubling scheme. 


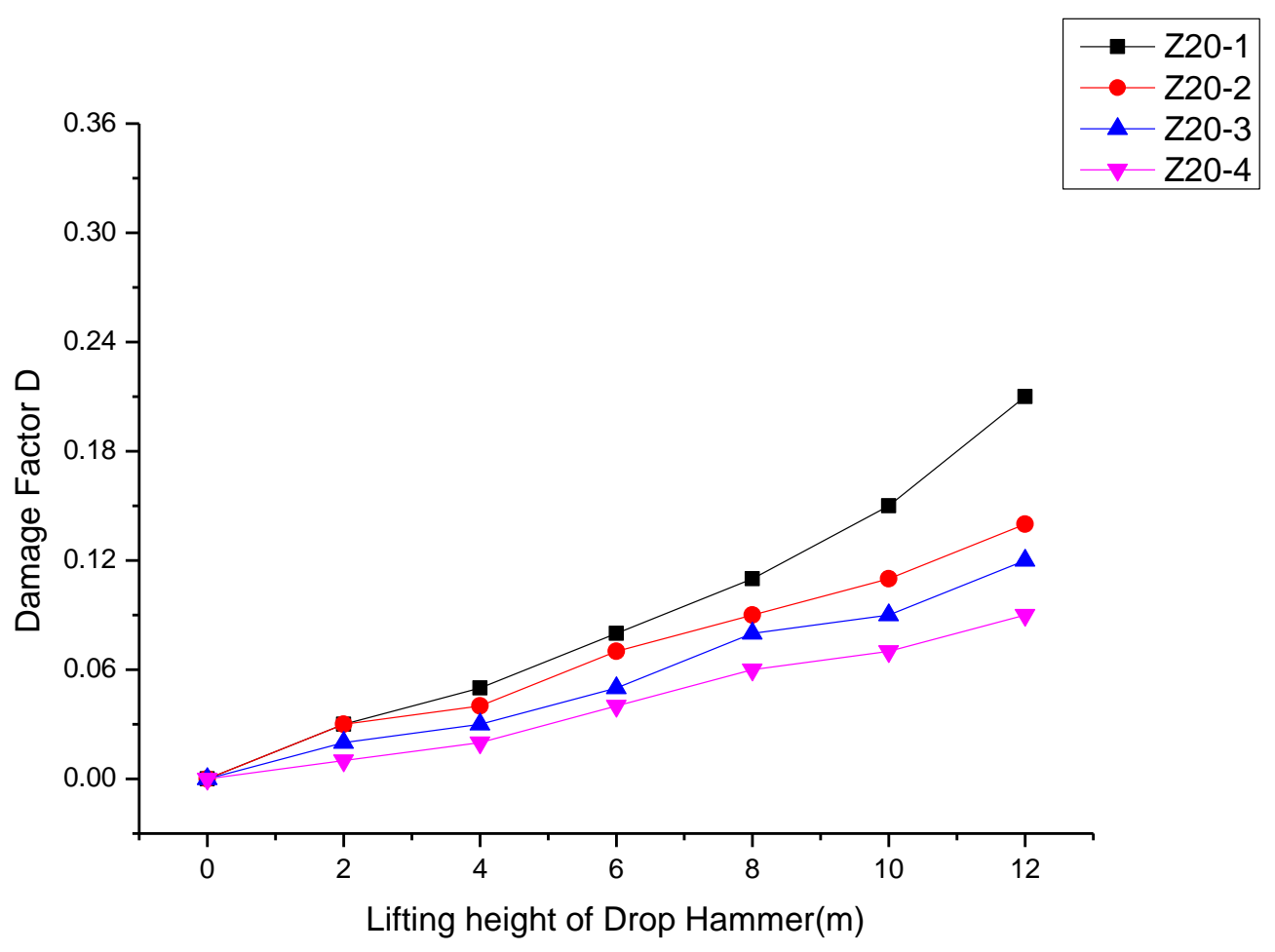

Figure 9. Changes of Damage Factors

Fig. 9 shows the changes of damage factors of specimen when the drop hammer is lifted to the height of $2 \mathrm{~m}, 4 \mathrm{~m}, 6 \mathrm{~m}, 8 \mathrm{~m}, 10 \mathrm{~m}$ and $12 \mathrm{~m}$ respectively. It can be known from the Fig.9 that the damage factor of concrete specimen will increase with the growth of the impact energy and the law of change is consistent. Under the low-energy impact effect, the damage factors of specimens have a small difference if the drop hammer is lifted to the height of $0-4 \mathrm{~m}$, which means that the use of closed-cell foam aluminum buffer materials has no obvious effect under the low-energy impact. Under the high-energy impact, the damage factors of specimens have a large difference when the drop hammer is lifted to the height of $8-12 \mathrm{~m}$; the damage factor of specimen using the closed-cell foam aluminum buffer material has an obviously lower increase rate than the specimen without using the buffer materials, and the approximate density doubling scheme of foam aluminum has a better buffer effect than the thickness doubling scheme.

\section{Conclusion}

The domestically most advanced multi-functional ultrahigh heavy type drop-hammer tester is used in this paper, and the closed-cell foam aluminum buffer material with different thicknesses and densities is designed at the head position of the impact cart; multiple cumulative transverse impact tests are performed on 4 pieces of reinforced concrete bridge pier specimens. Through the analysis on the cracks in main failure area, ultrasonic sound velocity and damage factor of specimen, the following main conclusions are reached:

Major cracks of specimen after impact mainly appear in the bottom area of specimen and gradually develop towards the middle area of specimen. The use of closed-cell foam aluminum as the impact buffer material can effectively reduce the derivation and development of major cracks of specimen; the increase of density or thickness of closed-cell foam aluminum brings a more obvious impact buffer effect, and the density doubling scheme of the closed-cell foam aluminum has a better impact buffer effect than the thickness doubling scheme.

The law of change of ultrasonic sound velocity and damage factor of each impact specimen is consistent with the growth of the impact energy, the average ultrasonic sound velocity of impact specimen will decrease gradually with the growth of the impact energy, and the damage factor of 
impact specimen will increase with the growth of the impact energy.

The average ultrasonic sound velocity change rates and damage factors of specimens have a small difference under the low-energy impact effect of bridge pier specimen, which means that the specimen damage is small during the low-energy impact and the buffer effect of the closed-cell foam aluminum is not obvious.

Under the high-energy impact effect, the average ultrasonic sound velocity change rates and damage factors of bridge pier specimens have a larger difference, which means that the specimen damage is large during the high-energy impact, the buffer effect of closed-cell foam aluminum is obvious and the density doubling scheme has bring a better buffer effect than the thickness doubling scheme.

\section{Acknowledgements}

The research described in this paper was sponsored by the Major Project (Natural Science) of Department of Education of Guangdong Province (2014KZDXM064), th e Science and Technology Innovation Project of Department of Education of Guangdong Province (2013KJCX0188), and the Civil Engineering Technology Research Center of Guangdong Province.

\section{References}

[1] Chen Guoyu. Pier Collision Avoidance in the Middle Reaches of Changjiang River[J]. Navigation Technology News, 1995, (3):14-18. In Chinese

[2] Wang Shiming. Experimental study on mechanical and damage characteristics of early age concrete under impact load [D]. Central South University, 2014. In Chinese

[3] Tian Yubin, Huang Tao, Liu Jia, Jin Ruoxi and Zhang Chunwei. Experimental study on damage performance of impacted concrete [J]. Journal of Building Structures, 2014,(S1):58-64. In Chinese

[4] Tian Li and Zhu Cong. Damage assessment and protection technology of reinforced concrete columns under impact impact load [J].Engineering Mechanics, 2013,(09):144-150+157. In Chinese

[5] Huang Tao. Study on mechanical properties of impact damaged concrete [D]. Harbin Institute of Technology, 2013. In Chinese

[6] H.Ohnuma,C.Ito,S.G.Nomachi. Dynamic response and local rupture of reinforced concrete beam and slab under impact loading. Mechanics in Reactor Technology, 1985: 179-184.

[7] Cook D J, Chindaprasirt P. Influence of loading history upon the tensile properties of concret [J] .Magizine Concrete research, 1981, 33( 116) : 154-160.

[8] Lan Fengchong, Zeng Fanbo, Zhou Yunjiao and Chen Jiqing. Research progress on mechanical properties of closed-cell foam aluminum and its application in energy absorption of vehicle collision [J]. Chinese Journal of Mechanical Engineering, 2014,50(22):97-112. In Chinese

[9] Kang Ying'an, Zhang Junyan and Tan Jiacai. Influence of relative density on mechanical properties and energy absorption properties of foam aluminum [J]. Journal of Functional Materials, 2006,(02):247-249+254. In Chinese

[10]Zhang Fuzeng, Qi Lukuan and Zhao Meng. Application of sandwich aluminum foam structure in collision avoidance of bridge structure [J]. Highway, 2017,62(06):94-98. In Chinese

[11]Zhu Cong. Dynamic response and damage mechanism of reinforced concrete structure under collision and impact load [D]. Tianjin University, 2012. In Chinese

[12]Xu Dongfeng. Study on the application of foam aluminum protection device in bridge pier [D]. Chongqing Jiaotong University, 2006. In Chinese

[13]Liu Huan. Study on the energy absorption and explosion-proof characteristics of aluminum foam materials [D]. Northeastern University, 2014. In Chinese

[14]Li Binchao, Zhao Guiping and Lu Tianjian. Critical conditions and optimum design of low speed impact protection for closed-cell foam aluminum [J]. Chinese Journal of Solid Mechanics, 
2011,32(04):325-338. In Chinese

[15] Santoaa S, Wierzhicki T.0n the modeling of crush behavior of a closed-cell aluminum foam structure[J].J Mech Phys Solids.1998.46(4).645-669

[16] Yu J L, Li J R , Hu S S, etal. Strain-rate effect and micro-structural optimization of cellular metals [J] .Mechanics of Materials , 2006, 38: 160-170. 